\title{
Values, company culture and strategy: CSR reporting at Southwest Airlines
}

\author{
Thaddeus Gabreski \\ Wildau Institute of Technology, Technical University of Applied Sciences Wildau
}

\begin{abstract}
Southwest Airlines, an American stock company headquartered in Dallas, Texas, has been an early pioneer of "nofrills" airline services - some see Southwest as the mother of all low-cost carriers, developing a distinct business model. The iconic firm is also known for a unique corporate culture and management style. The "Southwest Way" is linked to key elements of corporate social responsibility (CSR) concepts, mirroring values. In the context of company strategy and a brief SWOT analysis, this paper analyzes and evaluates the firm's CSR reporting in its 2011 "Southwest One" report. This report is judged on its communication style about work culture, business ethics, community investment and environmental impact of the airline.
\end{abstract}

Keywords: airlines, air transport, corporate social responsibility, CSR reporting, community relations, environment, Global Reporting Initiative (GRI)

Author: Thaddeus Gabreski is a student in the Master's in Aviation Management program at Wildau Institute of Technology (WIT) at Technical University of Applied Sciences Wildau. He holds a M.Sc. in International Business (with an emphasis in marketing) from London South Bank University. He has worked in California, New York and Vietnam.

\section{Introduction}

In Europe, Southwest Airlines is not a well-known name except among frequent North American travelers - or experts and students of aviation management. A pioneer of the low-cost airline business model with a unique brand and somewhat quirky character, Southwest Airlines is a leader in all aspects of the industry for innovative ideas, customer service and accomplishments for the past 40 years. Accomplishments range from the beginning of operations in 1971 all the way to the modern jet age. In this turbulent industry, Southwest maintained a consistent profit for 39 consecutive years. This is unheard of in the United States airline industry.

Southwest Airlines in the beginning incorporated a very unique company culture into its business structure. "It's living the Southwest Way - a warrior spirit, a servant's heart, and a fun-luving attitude," as the firm states in its "Southwest One Report" (Southwest Airlines, 2011, p.31). This different work culture at Southwest keeps thriving and continues to impact the bottom line as the airline continues to grow. Performance, people and planet represent the passion of the airline and helps define the "Southwest Way." The successful performance is consistent as a result of motivated employees, meeting the expectations of customers and shareholders, while controlling the overall cost structure of the airline.

This paper discusses the key elements of Corporate Social Responsibility (CSR) reporting in an organization and how management style reflects the value of a company and uses Southwest Airlines as an example. The airline is known for having a sound corporate culture and a business strategy that remains competitive in the industry. The airline utilizes its efficiency, innovation, quality and customer satisfaction as a formula for success in the industry that competitors find difficulties in copying.

In the CSR report, the passions of Southwest focus on performance, people and the planet. These three sections are divided equally in regards to how much information is reported and each section highlights the importance of the Southwest people. These passions revolve around the idea of running a business by putting it employees first and in return the people at Southwest deliver great customer service.

The overall structure of the discussion uses the 2011 "Southwest One" report and additional company publications and aviation industry-related trade media articles. The first part starts with the background, strategy and a SWOT analysis for a general understanding of the general business climate of Southwest Airlines. This clarifies some of the key characteristics that differentiates Southwest from competitors. The second part entails a discussion highlighting the work culture, business ethics, community investment and environmental impact of the airline as published by the airline and from other media sources. Finally, a conclusion emphasizes the importance of how CSR reflects the values of an organization.

In Southwest Airlines' report, performance indicators are analyzed not only for one year, but also for multiple years in some of the flight operation categories. The important "Key Performance Indicators", or KPIs, in the airline industry include flight operations, customer service and financial categories. These categories are then broken down to more specific areas within the broader ones.

For 2011, a big jump in revenue and overall KPIs occurred when Southwest acquired the low-cost carrier AirTran Airways (formerly ValuJet Airlines). For example in 2011, Southwest Airlines 
fleet consisted of 698 versus 548 aircraft in 2010. The fleet increase resulted from adding AirTran's fleet to Southwest Airlines. The airline changed quickly overnight with the addition of AirTran Airways into the Southwest portfolio. The report discusses the merger in depth and how they are integrating the people from AirTran to the Southwest culture. As mentioned earlier, the Southwest culture is unique and integration of a different culture could prove risky. The report explains terms and focuses on mainly the positive factors contributing to the success of the airline. In order for future success, Southwest orchestrates a very detailed integration strategy.

\section{CSR reports and airlines}

CSR reporting in the airline industry is about building trust with management, shareholders and the community by implementing strategies that add value to a company. Company goals in the report should revolve around a good balance between social issues and financial performers that satisfy stakeholders. The idea is to report corporate sustainability and financial matters in one report. The integrated reports allow stakeholders to compare risk with performance.

However, some issues arise from the indicators that airlines report because there is a not an authority to guide in the reporting process. Therefore, a set of Global Reporting Initative's (GRI) standards for airlines to adhere to is an important first step to implement in how airlines report data. For example, miles and kilometers are used differently by airlines and a lot of times this is not clarified in the report (Preston and Ruske, 2011, p.6). Overall, a standard in the industry should be established for easier comparison amongst others in the same industry.

Independent accounting firm giant PricewaterhouseCoopers (Preston and Ruske, 2011) has proposed the following steps to boost the quality of CSR reporting:

- A clear link of corporate sustainability with overall goals, strategy and vision;

- credible, relevant data that is easily understood; and

- industry standards to improve reports for easy comparisons.

It is interesting to note that standards for non-financial reporting are beginning to change with new initiatives taking place to define parameters. For example, GRI is an agency that offers specific sector supplements to aid in reporting standards (Eccles, 2012, p. 66). However, unlike financial reporting, which has strict guidelines that are established by the Financial Accounting Standards Board (FASB), do not exist in the area of non-financial report practices. The standards in the industry for financial reporting are well established and have an institutional authority for companies to follow, whereas GRI only suggests standards.

Southwest Airlines' report discloses the information used in how they report their data and goes above and beyond the minimum standards or suggested KPI's when they report. Southwest tops the list of high quality reporting amongst other airlines, according to PricewaterhouseCoopers (Ruske and Preston, 2011, p. 10). They do a good job in the company profile section, offering much more data than the minimum, which is consistent with CSR policy and gives clear data to stakeholders (p.10). Southwest Airlines reaches out to a broad audience in their CSR report.

Southwest Airlines reports use the Global Reporting Initiative's (GRI) B+ application level, which is externally assured. There are three different application levels in the GRI reporting criteria, A, $\mathrm{B}$ and $\mathrm{C}$. The $\mathrm{B}+$ level incorporates three different disclosure levels that include a company profile, managements approach and performance indicators related to the airline and specific industry. The final report must include at least 20 performance indicators with at least one from the following list according to GRI guidelines (GRI Application levels, 2011, p.3): economic, environment, human rights, labor, society, and product responsibility.

\section{Company background}

Southwest Airlines is a low-cost airline in the United States that offers low prices to its customers. Established in 1971, the company flies the largest amount of passengers annually together with the newly acquired AirTran Airways subsidiary with nearly 3,800 daily flights to 97 destinations with a fleet of 692 Boeing aircraft a year (Southwest Airlines, 2011). The firm's success is based on low costs, low fares, frequent flights and new cities.

Characteristically, Southwest offers point-to-point services in the United States. Its route network does not follow the traditional hub-and-spoke model which relies on connecting flight services. The point-to-point model has only origin and destination traffic to consider. In practical terms, this reduces trip time by allowing more non-stop service to cities with minimal delays by operating at less congested airports. The point-to-point service strategy optimizes schedules and reduces turnaround time.

Southwest's business model and basic strategies have become mainstays of industry conference talks and business school textbooks, and of course many practical attempts to copy and repeat Southwest's example. Ryanair of Ireland and EasyJet of Britain are the best known copiers in Europe (but it should be noted that both their management models and their company culture today differ greatly from the original).

The extensive literature about Southwest strategy - from industry practitioners' views to scholarly studies - need not be discussed here at length. As a simple summary, the Southwest strategy relies on the following characteristics for success:

\begin{tabular}{|l|}
\hline \multicolumn{1}{|c|}{ Table 1: Southwest strategy overview } \\
\hline Operating strategy \\
Operates one aircraft type \\
Flying to cheaper less congested airports \\
Mechanics Pilots are trained on one aircraft \\
Faster turnaround time of aircraft \\
\hline Marketing strategy \\
Offering direct flights to cities across the United States \\
Open seating policy \\
Serving snacks only \\
Utilizing own distribution system \\
Lower fares than competitors \\
\hline Human resources strategy \\
Cross training and flexible workforce \\
Never any lay offs \\
High productivity with higher wages than other airlines \\
\hline
\end{tabular}

Table 1: Southwest strategy overview

\section{A simple SWOT analysis}

A general context-sensitive assessment of Southwest Airlines' strengths, weaknesses, opportunities, and threats helps profile the company. Strengths are those elements which give Southwest an advantage over other airlines. Weaknesses, by contrast, are disadvantages in competition.

Strengths and weaknesses are both understood to be of internal origin, i.e. they are the direct result of the firm's own decisions 
about its structures, processes, personnel, technology, communications, and so on.

Opportunities are external factors which the firm could use to increase its advantage, and threats then are those environment factors which might lead to new disadvantages. The environment is understood to include both market and non-market factors which are relevant for the air transport industry and Southwest Airlines.

Without offering any discussion about the miscellaneous factors, a basic SWOT matrix for Southwest Airlines may be sketched like this:

\begin{tabular}{|c|c|c|}
\hline \multicolumn{3}{|c|}{ Table 2: SWOT analysis } \\
\hline 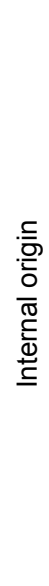 & $\begin{array}{l}\text { Strengths } \\
\text { - } \quad \text { Operating strategy de- } \\
\text { fined } \\
\text { - } \quad \text { Standardization of fleet } \\
\text { - } \quad \text { Customer service } \\
\text { friendly } \\
\text { - } \quad \text { Best low cost carrier } \\
\text { - } \quad \text { Excellent service } \\
\text { - } \quad \text { Experience of over } 40 \\
\text { - } \quad \text { ears in the industry } \\
\quad \text { rier in terms of passen- } \\
\text { - gers } \\
\text { - } \quad \text { Sood labor relations } \\
\text { - } \quad \text { Create mank image } \\
\text { - }\end{array}$ & $\begin{array}{l}\text { Weaknesses } \\
\text { - Declining profits } \\
\text { and margins } \\
\text { - Contractual obliga- } \\
\text { tions } \\
\text { - Higher wages } \\
\text { than competitors } \\
\text { - Conservative } \\
\text { growth strategy } \\
\text { - Growth opportunities } \\
\text { limited with current } \\
\text { strategy } \\
\text { - Limited booking } \\
\text { system } \\
\text { - Limited market seg- } \\
\text { mentation (no busi- } \\
\text { ness class, lounges) }\end{array}$ \\
\hline 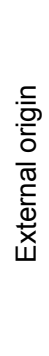 & $\begin{array}{l}\text { Opportunities } \\
\text { - Industry is rebounding } \\
\text { - International expansion } \\
\text { - Merged with AirTran to } \\
\text { gain market share in } \\
\text { restricted areas (New } \\
\text { York City, Washington } \\
\text { D.C and Atlanta) } \\
\text { - Grow in the largest air- } \\
\text { line market }\end{array}$ & $\begin{array}{l}\text { Threats } \\
\text { - Competition } \\
\text { - Regulations } \\
\text { - Oil prices } \\
\text { - Downturn in economy } \\
\text { - Integrating AirTran } \\
\text { culture can be nega- } \\
\text { tive }\end{array}$ \\
\hline
\end{tabular}

Table 2: SWOT analysis

\section{Southwest Airlines and market share}

Gaining market share has been an important strategy element for the growth of Southwest and can be linked to the profitability of the company. The successful business model operates with lower unit costs, higher profits and an ability to grow. It is estimated that Southwest Airlines market share is at 70 percent in the top 100 city-pair markets (Southwest Airlines, 2011).

Southwest Airlines competes for market share less in the top 100 markets for which they serve. For this reason, Southwest's ability to expand output faster than rivals in its markets gains a wider cost differential in the market. There exists a positive relationship between market share and profitability that Southwest Airlines benefits from. The influence of market share and offering a differentiated product promotes profitability and is important for success. Superior efficiency, customer service and product innovation are the three areas support profitability of the carrier (Grant, 2005, p.250-253).

As the company's "Southwest One" report emphasizes in its performance-related section, Southwest enters a market offering low fares, great customer service and innovation to promote quick growth. The airline establishes market share by entering markets that have little competition and quickly gains passengers and reports high profits. Creating market share is an important strategy for Southwest and has proved effective for maintaining performance.

\section{Business ethics}

\section{Work culture}

Southwest, according to Bryant (2007), believes the success of the organization comes from the relationship with their employees and a potential candidate must fit within the value element of

the warrior spirit, which encompasses everything that is required to achieve excellence a servant's heart, which means putting others before yourself and a fun-luving [sic] attitude, which means not taking yourself too seriously, enjoying work, and maintaining balance in your life. (p.36)

Training and developing at Southwest is put on a pedestal. The passion of leading is important across the whole work culture. The potential for developing in all directions is possible at the airline. The human resources team hires for attitude and not just for skills. Leadership and developing is a key element for success and the CSR report mentions many different training areas that help develop the employee.

Southwest invests heavily in this. It was estimated that a few years ago, the learning hours for leadership development doubled for employees and the outcome improved customer satisfaction scores (Bryant, 2007, p.38). The culture at southwest is unique and performs well to the overall performance of the company. The CSR report highlights all the important factors that have led to the success.

\section{Servant-leadership}

The idea behind servant style leadership focuses first on the needs of employees and customers, as Kent Keith, CEO of Greenleaf Center for Servant Leadership, explains:

If you really listen to your colleagues and figure out how to get them what they need, they will perform at a higher level, which improves the customer experience, which affects business results (quot. Johnson, 2012).

Southwest Airlines corporate culture embraces servant leadership as a method within the company. Former CEO Herb Kelleher believes his flight attendants are the most important leaders because they impact the customers the most (Johnson, 2012).

Southwest Airlines does have policies intact to promote a positive environment for flight crews. The report highlights this type of leadership as a factor for the airlines success.

\section{Customer service and employees}

This area of the business is very important for the airline and overall strategy recognizes this as a key element for success. The official homepage of Southwest declares that its people thinks of themselves as a customer service company that flies airplanes. From the hiring process, ongoing training and service standards deems important for success and is a factor that raises the performance.

The core competencies incorporated with the business strategy include specific skills, knowledge and experiences. These elements allow the organization to perform better (Mujtaba \& Wright, 2011, p.77). The employees deliver high customer service standards to customers that stem form the core values of the culture itself. The company focuses on the employee by understanding that a well-trained, well-cared-for, well-informed and empowered employee is a valued resource for the company (p.83). 
In maintaining this policy for the new AirTran employees being implemented into the Southwest team, the airline highlights the integration policy on how to assimilate two different cultures to one. As mentioned in the One Report, Southwest culture is the core and a key element in success (One Report, 2011, p.33). The Southwest principles are highlighted in the following and emphasized in the report:

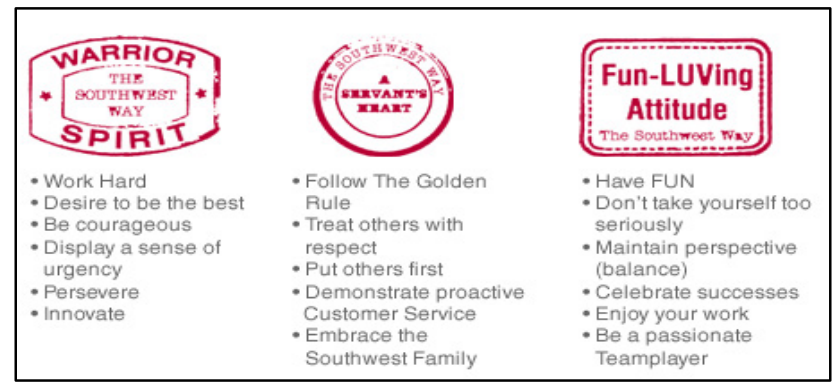

Figure 2: Principles of Living the Southwest Way (Southwest Airlines, 2011)

This includes several programs and opportunities for current Southwest employees to meet the new AirTran personnel. The AirTran employees learn about the culture of Southwest in various formats at a reasonable pace. Both cultures are working with each other to learn about the differences and teach them the "Southwest Way." The CSR report is filled with information relating to the merger and how Southwest manages to implement the new employees with preserving the work culture. The Southwest strategy has proven successful and current management wants to continue in this direction by highlighting the importance of integrating the two cultures successfully.

\section{Training failure}

How does Southwest deal with negative media when a pilot does not perform to the core values of the company? As mentioned time after time, Southwest is known for great customer service, a great work culture and continuous profitability year after year. However, one incident occurred in 2011 when a pilot expressed anger about the hiring of gays, grannies and large people for flight attendants during a flight live on Air Traffic Control radio. The pilot was immediately suspended and a Southwest spokesperson said,

we've built our company's reputation on the Golden Rule: treating others as you would like to be treated. The actions of this pilot are, without question, inconsistent with the professional behavior and overall respect that we require from our employees (quot. Mutzabaugh, 2011).

The pilot is required to attend diversity training and inclusion classes as ongoing training.

Diversity and acceptance in the workplace is a focus of Southwest and is continually being monitored to preserve the culture (Mutabaugh, 2011).

\section{Customer service priority}

Listening to customers is a priority for the airline and demonstrates this by tracking customer comments. The company estimates that for every eight positive comments, there is one rude customer complaint (One Report, 2011, p.48). As an ongoing effort, the airline sends 10,000 emails daily to randomly selected customers. The high response rate is then used to calculate a Net
Promoter Score (NPS) that is the outcome of customers that recommend the airline versus the customers that do not. The goal for the next year is to beat the current score.

This is one system that Southwest uses to constantly improve customer service. Southwest does not mention negative events in the CSR report, but elaborates on areas and training that should reduce this.

Transparency in information is available when navigating the company's website. The website is user-friendly and information is easy to find regarding operating procedures and management practices. The CSR does a good job at accentuating in areas that it does an outstanding job at. For example, Southwest leads the industry in customer satisfaction scores. The following information is highlighted in the report:

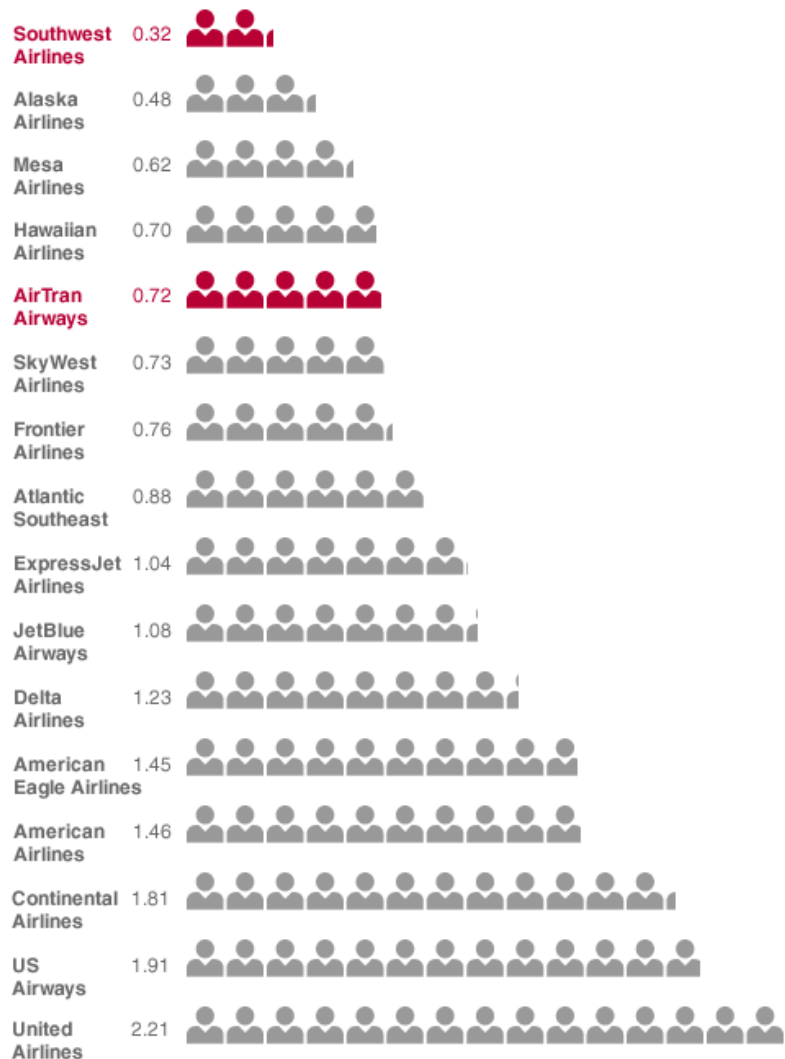

Figure 3. Customer satisfaction, as measured by consumer complaints per 100,000 enplanements. With this chart, the company claims: "In 2011, Southwest Airlines once again had the lowest ratio of complaints per customers boarded of all major U.S. carriers, according to the U.S. Department of Transportation's Air Travel Consumer Report" (Southwest Airlines, 2011).

However, there are many other categories where the report is lacking in substance. For example, the airline is not a leader in ontime performance, flight cancellations and lost luggage. Southwest reports the statistics for the above information, but does not compare them to other airlines in the industry. Southwest rated second-to-last in the lost-luggage category in 2011 (McCartney, 2012).

The comparison of the year 2010 and 2011 are mentioned in the CSR report, but it is lacking the ranks amongst other carriers. The report identifies the statistics by comparing them with themselves and does not acknowledge underperformance in some categories to their stakeholders (Southwest Airlines, 2011, p.49). 


\section{Community involvement}

Investing in the communities that Southwest serves is not a new task for the airline. According to Bloomberg Business Week, Southwest is ranked in the top 20 for working in the communities. Southwest employees volunteered 114,000 hours in 2011 for charitable organizations. The programs involved "Adopt-A-Pilot" that provides aviation themed activities to about 349,000 students in communities (Brady, 2012). Also, the donation of roundtrip tickets to non-profit groups is a program that Southwest supports. Said Ginger Hardage, Senior Vice President of Culture \& Communications at Southwest Airlines,

At Southwest, we consider citizenship an extension of our mission and longstanding history to do the right thing for our People, our Communities, and our Planet, while maintaining our commitment to sustaining a strong business model (Southwest Airlines, 2012).

With this community tradition, Southwest supports emergency response efforts, grassroots campaigns, charities and the U.S. military. This is elaborated in the report. Southwest participates in one special "Honor Flight Network" (www.honorflight.org) which flies veterans to national war memorials. The company states, it is proud "to have the opportunity to give back to the people who have fought to protect our freedoms" (Southwest Airlines, 2012). This program for military personnel benefits 3,000 veterans with US $\$ 1.2$ million in travel privileges from 2012 to 2015. In addition to this, Southwest supports military families in need. The report emphasizes these programs that Southwest provides assistance for. This importance of supporting the community provides for a positive image for a company and contributes to the profitability.

Southwest supports employees reaching out to special interest groups by encouraging individual employees to support their cause. Diversity is important within the Southwest culture, as well as supporting outside interest groups. The airline supports "outreach" programs for African American, Asian American, Hispanic, and also lesbian, gay, bisexual, and transgender (LGBT) communities (Southwest Airlines, 2011, p.59). Outreach programs benefit people through different types of programs. They support by giving scholarships, establishing community partnerships and alliances. Employees are encouraged to volunteer 40 hours of time and are rewarded with special prizes. Emphasis in the report is supporting the employee helps Southwest distinguish itself from other airlines.

The commitment to supporting communities is outlined in the report with personal stories and recognition programs for employee outreach to the communities. The report is about personal encounters of how the people of Southwest make the difference. Southwest rewards employees for outstanding service and volunteering. A positive impact is created on communities with volunteering, giving to charities and good citizenship. The airline rewards employees who deliver world class Customer Service, operational excellence and willing to do the right thing (Southwest Airlines, 2011, p.41). The programs are highlighted in the report.

\section{Environmental impact}

This successful strategy of the airline continues with implementing an Environmental policy to help the earth. Southwest refers to the environmental policy as a "green filter" and the CSR report defines all the activities that are involved in protecting the planet. The airline is active in the community with implementation of 40 conservation projects in celebration of 40 years of service in communities for which Southwest flies. These projects outline the importance giving back to the communities. For example, a total of 1,000 trees were planted, restoring 9 miles of trails and removing 58 truckloads of invasive species (Southwest Airlines, 2011, p.72). The figures for which Southwest uses in the report are easily understood. It is important that the airline also links the environment strategy with people section in the CSR report.

Environmental impact at Southwest is measured with how many fines and sanctions have been received from violating compliance laws. The transparency in the report highlights the past four years with the monetary amount in fines and number of hazardous material spills occurring at the airline. The report states that Southwest strives to become an airline that continues to reduce carbon emissions by fleet renewal and modifications, recycling and refurbishing their current fleet with recyclable materials. According to Southwest, the new interior was

inspired by Southwest's past with a nod to the airline's future, the cabin refresh features recyclable carpet, a brighter color-scheme, and a more durable, eco-friendly, and comfortable low-profile seat (Siegel, 2012).

This addition reduces weight on the aircraft and saves the airline money and increases comfort for passengers.

Navigation is an area where the airline is trimming costs - but also reducing waste and emissions - by implementing equipment on its fleet to help save fuel, and by implementing more efficient flight procedures. "Required Navigation Performance" (RNP) is based on a project partnering with aircraft manufacturers, avionics industry, and satellite navigation services. Essentially a new method in air traffic control, RNP, in the words of Vice President for Operations Coordination Center Jeff Martin,

sets the stage for Southwest to continue doing its part to conserve fuel, improve safety, and reduce carbon emissions and greenhouse gases, while simultaneously taking advantage of the high-performance characteristics that exist in an airline's fleet (Karp, 2011).

All these enhancements are directly linked in the CSR report and emphasized as a way forward.

The CSR report highlights recycling efforts used daily and reports on future initiatives that play a role that emphasizes Southwest Airlines dedication to protecting the planet. The report is often biased in the fact that the comparison across other airlines is not included, but does include elements that other airlines omit altogether.

For example, a PriceWaterhouseCoopers study concluded that 70 percent of reports sampled reported $\mathrm{CO}_{2}$ emissions, 67 percent fuel efficiency and 40 percent included waste and water consumption (Preston and Ruske, 2011, p.19). Southwest Airlines reports on various environmental levels that other airlines do not include. The airline achieved a higher ranking than other carriers.

\section{Conclusions}

CSR reporting is a complex issue for organizations when deciding what tactics to use that will benefit the company the most. It is important for Southwest Airlines to take a balanced approach on how they interact with society. In doing so, they should continue to offer activities without compromising their beliefs. The airline is focused on creating value in the long term as well as concentrating on what matters most in today's operating environment.

Southwest incorporates a diversified policy in its approach to CSR, while exceeding the expectations currently established for CSR reporting. The airline has a clear understanding of the benefits, aligning activities with their values and supportive of their strategic priorities. As literature suggests that CSR reporting is gaining momentum and a set of standards would benefit on how and what organizations report.

Overall, Southwest has a keen interest in their employees and expects them to share the same ideals as the business was founded on. The culture has a strong desire to support its missions and goals and the CSR report highlights the diverse nature of the company. 
The report is fairly transparent in many issues and leaves a good impression to shareholders and readers. Southwest stays focused on their three passions-Performance, People and Planet and the CSR report reflects this throughout.

\section{References}

Brady, D (2012, November 8). Volunteerism as a core competency. Bloomberg Business Week. Retrieved from http://images.businessweek.com/slideshows/2012-11-08/civics-lessons\#slide2

Bryant, E. (2007, December). Leadership Southwest. $T+D$ Training and Development, 36-39. Retrieved from http://www.paradigmlearning.com/Libraries/Articles/AR-T-D-Southwest-Story.sflb.ashx

Eccles, R., Krzus, M. P., Rogers, J., \& Serafeim, G. (2012, Spring). The need for sector-specific materiality and sustainability reporting standards. Journal of Applied Corporate Finance 24, 65-71. Retrieved from http://www.sasb.org/wp-content/uploads/2012/06/JACF-Sector-Materiality.pdf

Grant, R. M. (2005). Contemporary strategy analysis. Oxford: Blackwell.

GRI Application Levels. (2011). AL GRI Application Levels. Retrieved from https://www.globalreporting.org/resourcelibrary/G3.1-Application-Levels.pdf

Johnson, E. (2012) How to: become a servant leader. Success Magazine. Retrieved from http://www.success.com/articles/1625-how-to-becomea-servant-leader

Karp, A. (2011, January 12). Southwest starts using RNP procedures at 11 airports. ATW: Air Transport World. Retrieved from http://atwonline.com/airports-routes/news/southwest-starts-using-rnp-procedures-11-airports-0111

McCartney, S. (2012, January 5). The airline that loses bags, cancels flights. The Wall Street Journal. Retrieved from http://online.wsj.com/article/SB10001424052970204331304577140740389194590.html\#

Mujtaba, B. G. \& Wright, A. (2011, June 3). Southwest Airlines and management: becoming an industry leader in the modern workplace. Journal of Research in International Business and Management 1, 77 84. Retrieved from http://interesjournals.org/JRIBM/pdf/2011/June/Wright\%20and\%20Mujtaba.pdf

Mutzabaugh, B. (2011, June 23). Southwest pilot suspended for slurlaced rant on air-traffic frequency. USA Today. Retrieved from http://travel.usatoday.com/flights/post/2011/06/southwest-pilot $/ 175250 / 1$

Preston, M. \& Ruske, K.-D. (2011, November). Building trust in the air: is airline corporate sustainability taking off? Price Waterhouse Coopers. Retrieved from http://www.pwc.com/en_GX/gx/sustainability/assets/pwc-airlines-cr.pdf

Siegel, R. P. (2012, January 19). Southwest Airlines' cabin experience evolves in a sustainable direction. Triple Pundit: People, Planet, Profit. Retrieved from http://www.triplepundit.com/2012/01/98266/

Southwest Airlines (2011). 2011 Southwest Airlines One Report. Three passions. One Southwest: our performance, our people, and our planet. Retrieved from http://www.southwestonereport.com/2011/

Southwest Airlines (2012, November 9). The Civic 50 names Southwest Airlines in top 20 of most community-minded companies in America. [LUV: Investor Relations.] Retrieved from http://southwest.investorroom.com/2012-11-09-The-Civic-50-Names-Southwest-Airlines-InTop-20-Of-Most-Community-Minded-Companies-In-America

Southwest Airlines. (2012, July 17). Southwest Airlines to provide $\$ 1.2$ million in free travel for America's World War II veterans. [LUV: Investor Relations.] Retrieved from http://www.prnewswire.com/news-releases/southwest-airlines-to-provide-12-million-in-free-travel-for-americas-world-war-ii-veterans-162723276.html 